\title{
Cautionary Tale of the Picture of Dorian Gray: Parable and Autobiography
}

$$
\text { Mikail PUŞKİN }{ }^{1}
$$

\begin{abstract}
Current research paper performs focused textual analysis of themes and characters of the novel The Picture of Dorian Gray by Oscar Wilde intertwining the study with pertinent references to details of the author's biography thus providing essential critical insights. Peculiarity of the paper lays with it considering the novel to encompass two distinct juxtaposed genres: an autobiography (decadent values) and a parable (moral values). By synthetically combining them, the author at the same time conveys superiority of idealized artistic aesthetic worldview of reality (at times superseding conventional morality) while reinforcing fundamental if naïve good nature of humanity with both of them engaged in (endless) struggle for the reader's soul against the suffocating reality of hypocritical society.
\end{abstract}

\author{
Keywords \\ morality \\ autobiography \\ decadence \\ social criticism \\ realism \\ Oscar Wilde
}

About Article

Received: 15.01.2021

Accepted: 23.03.2021

Doi:

10.20304/humanitas.861739

\section{Dorian Gray'in Portresinin Uyarıcı Hikayesi: Kıssa ve Otobiyografi}

\section{$\ddot{O} \mathbf{z}$}

Mevcut araştırma makalesi, Oscar Wilde tarafından yazılan Dorian Gray'in Portresi romanının temalarının ve karakterlerinin odaklanmış metin analizini gerçekleştirerek, çalışmayı yazarın biyografisinin ayrıntılarına uygun referanslarla harmanlamakta ve temel eleştirel anlayışlar sağlamaktadır. Çalışmanın özelliğgi, romanı yan yana duran iki farklı türü kapsayacak şekilde düşünmekte yatmaktadır: otobiyografi (çökmekte olan değerler) ve benzetme (ahlaki değerler). Yazar bunları kurgusal olarak birleştirerek, aynı zamanda idealize edilmiş sanatsal estetik dünya görüşünün üstünlüğünü -zaman zaman geleneksel ahlakın yerini alıraktarırken ve insanlığın saf da olsa iyi doğasını güçlendirirken, her ikisi de riyakâr toplumun boğucu gerçekliğine karşı okuyucunun ruhu için (sonsuz) mücadeleye girişmektedir. Makale, araştırma iddialarını desteklemek için Wilde'ın aforizmaları ve alıntılarıyla destekleniyor.
Anahtar Sözcükler

ahlak

otobiyografi

çöküş

sosyal eleştiri

gerçekçilik

Oscar Wilde

Makale Hakında

Geliş Tarihi: 15.01.2021

Kabul Tarihi: 23.03.2021

Doi:

10.20304/humanitas.861739

\footnotetext{
${ }^{1}$ Asst. Prof. Dr., Agri Ibrahim Cecen University, Faculty of Science and Literature, Department of Sociology, Agri/Turkey, pushkin169@gmail.com, ORCID: 0000-0003-0467-1699
} 
Puşkin, M. (2021). Cautionary tale of the picture of Dorian Gray: Parable and autobiography.

\section{Introduction}

Without a doubt, so much is written about Oscar Wilde's work and life that one may find it impossible to make a meaningful academic contribution to the novel's understanding. A cautionary tale of Wilde's has become an inescapable self-fulfilling prophesy for the author leading to a trial and imprisonment some five years following its initial publication eventually causing his untimely death. However, to this day academicians have not ceased to debate its nature (form, aesthetics, genre) and through it - the meaning of The Picture of Dorian Gray. "Recent genre theory reminds us of just how often our disagreements about the meaning or interpretation of a text are actually debates about how the text should be read, or, more precisely, what kind of text it should be read as" (Clausson, 2003, p. 339). Current paper sides with the likes of Joseph Pearce and Joys Carol Oats, who consider the novel to be a kind of a fable "one sense The Picture of Dorian Gray is as transparent as a medieval allegory" (Oates, 1988, p. 422) or a parable: "the plot of the novel unfurls like a parable, illuminating the grave spiritual dangers involved in a life of immoral action and experiment" (Pearce, 2001, p. 164). Reading it arguably the way Wilde himself instructed: prioritizing not the form (mirroring appearance versus the deeds of Dorian), but the (moral and immoral) message of it.

Current research poses that the key (or one of the keys) to understanding Oscar Wilde's works is in processing its multiple aesthetic layers as intentionally misleading (one could argue them to be a kind of a prophetic metaphoric autobiography). Indeed, "all art is at once surface and symbol" (Wilde, 1998, p. 7). Reading the surface is what caused stir with Wilde's society and keeps confusing many a critic focusing on the surface as if it were dictating the meaning and substance rather than being a form of conveying it. Wilde's choice of the deep aesthetic surface is arguably his rebellion against "the crude brutality of plain realism" (Wilde, 2002, p. 436) as well as his personal choice or perhaps affliction of embodying all three protagonists of his novel in real life to much the same end: "Basil Hallward is what I think I am: Lord Henry what the world thinks me: Dorian what I would like to be-in other ages, perhaps" (Wilde, 2002, p. 585). Almost as if the author wrote two novels in one: one embedding and foreshadowing his biography and personality and a more universal moralistic parable. Such an approach is confirmed by the author: "the first condition of criticism is that the critic should be able to recognise that the sphere of Art and the sphere of Ethics are absolutely distinct and separate" (Wilde, 1966, p. 1048). Likewise, Wilde's personality and biography in the novel are separate from the novel's moral message: a 
Puşkin, M. (2021). Cautionary tale of the picture of Dorian Gray: Parable and autobiography. Humanitas, 9(18), 221-234.

depraved, witty, decadent gothic novel versus romantic yet moralistic cautionary tale of a parable.

Indeed, The Picture of Dorian Gray is a highly moral book in its message, although only partially is such in its formal storyline, characters, language and imagery. Provocateur Wilde exclaims "books are well written or badly written" (Wilde, 1998, p. 6) leading the reader to ask themselves - what is a well-written book? Is it something, easy and pleasing to read? Is it something interesting to read (clearly different things are interesting to different people)?

Believe it or not, there is still a secret left to be told about The Picture of Dorian Gray, a secret no less open, only less sensational than the scandalous passions all but named in the novel that all but exposed the secret of its author's own. Let's face it, the book is boring: for all the thrill of Dorian Gray, long stretches of the story are almost unbearably uninteresting (Nunokawa, 1996, p. 1).

Or does it stand for the clarity of the message that the author is attempting to convey to the readers? Was negative reaction of the contemporaries than confirming that The Picture of Dorian Gray is badly written? Even the almighty critics are far from reaching a concord:

Until the 1980s, The Picture of Dorian Gray was generally considered to be a deeply flawed novel. To some critics, it was simply badly written. To others, it was hopelessly confused, reflecting Wilde's uncertainty and irresolution. To still others, it was negligible or, at best, second-rate because it was merely an expression of the 1890s, in which case it was historically important but otherwise unworthy of critical attention (Liebman, 1999, p. 296).

\section{Analysis}

One of the most difficult times to write about is the time, which one lives in, - not only is the author open to critique, censorship and even attacks of their contemporaries, but is also faced with a daring task of understanding and representing the contemporary life by basing it on own direct experience of knowledgeable observer. One is thus stripped of holistic interconnected vision of events and actors offered by distanced perspective of a knowledgeable observer offered by retrospective fiction.

\section{The Society}

Let us then venture into the world of the novel and its inhabitants to arrive at the author's main message. The Picture of Dorian Gray is full of critique towards contemporary society. Most apparent ones are aphorisms of Lord Henry: 
Puşkin, M. (2021). Cautionary tale of the picture of Dorian Gray: Parable and autobiography. Humanitas, 9(18), 221-234.

It is perfectly monstrous the way people go about, nowadays, saying things against one behind one's back that are absolutely and entirely true (Wilde, 1998, p. 22). There is only one thing in the world worse than being talked about, and that is not being talked about (Wilde, 1998, p. 9). Men marry because they are tired; women, because they are curious; both are disappointed (Wilde, 1998, p. 62)...

Yet Lord Henry himself fits perfectly in this society and exploits its weaknesses, which he criticizes, to his own advantage. He therefore becomes the ultimate image of the 1890ies aristocratic society, immoral to the core, smart, sarcastic, hedonistic. However, with one exceptional trait noticed by Basil: "You never say a moral thing, and you never do a wrong thing" (Wilde, 1998, p. 13). This again pertains to Wilde's self-identification with Lord Henry, enamoured by decadent hedonism, the author believes himself to be pure through artistic worldview. He furthermore seduces Dorian into this lifestyle. However, while Lord Henry is very careful and sophisticated, Dorian (fatefully to materialize in Wilde's life the following year as Lord Alfred Douglas) is initially naïve and becomes vulgar in his plunging into the depth of immorality with only beauty to cover up for whatever sins he commits, which ironically is more than sufficient. "All crime is vulgar, just as all vulgarity is crime. It is not in you, Dorian, to commit a murder" (Wilde, 1998, p. 263). This is once again a criticism of contemporary society, where good looks count for more than good deeds: "The ugly and the stupid have the best of it in this world. They can sit at their ease and gape at the play “ (Wilde, 1998, p. 11). In this respect beautiful Dorian can do whatever he pleases and will be forgiven, since the society only values the superficial appearance and not the "content" of the person, while an extremely ugly person could also do anything regardless of the danger of spoiling the reputation: the society will condemn the person regardless.

Despite the passion with which Wilde despised hypocritical Victorian society, however, the focus of the novel is closely on the main characters rather than on the surrounding crowd, that acts either as a background chorus to support the main voices or as a canvas providing mostly victims to Dorian.

Certainly, this picture of the society did not win much social recognition - "The nineteenth century dislike of realism is the rage of Caliban seeing his own face in a glass" (Wilde, 1998, p. 6). In reception of the novel, however, the society chose to conceal the rage of seeing its ugliness, reflected in the portrait of Dorian, like in the mirror and in the best fashion of the aforementioned aphorisms chose to strike a completely different aspect of the novel: frivolous and homoerotic description of men's relationships in the book. Wilde's work was forced to be recalled and was continually partially rewritten and edited (Frankel, 2011, 
Puşkin, M. (2021). Cautionary tale of the picture of Dorian Gray: Parable and autobiography. Humanitas, 9(18), 221-234.

pp. 38-64). Would it be justified to claim that the book was not well-written? That the message was not well-expressed and therefore not clear to the contemporaries? Highly unlikely, since even the readers as distant from the narration time as ourselves are able to see that part of content and actually admire its irony.

\section{The Characters}

Let us now consider the major characters in greater detail. Dorian Gray is initially a strikingly handsome, impressionable naïve aristocratic young man. Poisoned by hedonistic philosophy of Lord Henry Wotton, he devotes himself to a decadent life of sensual pleasures beyond good and evil based solely on self-gratification. A fit made possible by exchanging his very soul for eternal untarnishable beauty. Naturally, his quest for pleasure and pain rapidly descends into immorality destroying lives of those around him an eventually his own, as being moral is more difficult and immoral pleasures are always within reach, particularly, when it is his portrait that gets to suffer the consequences.

Lord Henry Wotton is a sarcastic, witty charmingly corrupt noble speaking in eloquent epigrams criticizing the fake morality, vanity and duplicity of Victorian society. He defines and propagates the philosophy of new hedonism, which he also poisons Dorian with.

Basil Hallward is a painter, hopeless idealistic romantic and a friend to the both men. Basil becomes obsessed with Dorian. He sees in Dorian a beauty so rare that it helps him realize a new kind of art; through Dorian, he finds "the lines of a fresh school" (Wilde, 1998, p. 19). Deeply moral (overlooking the connotation of his homosexuality), fragile, sincere, romantic, he is reflective of Wilde's perception of himself.

Sibyl Vane (whose death, like for Basil is brought about by Dorian), a poor, beautiful and talented actress, whom Dorian falls in love with (which is mutual). Sibyl's feelings for Dorian compromise her ability to act, as her experience of true love in life makes her realize the falseness of enacted emotions onstage. Of those characters the successful in life ones are Lord Henry (though he is bittersweet at the end, but not broken) and Dorian, while Basil and Sibyl are somewhat of a failure in life - both end up unhappy and hurt, both seeking to hide from the cruel reality in art. Should we consider Oscar Wilde being immoral in his giving awards to the evil characters (even in death does Dorian suffer and atone fully for his sins)? Furthermore, according to the aphorism of Lord Henry: "When we are happy, we are always good, but when we are good, we are not always happy" (Wilde, 1998, p. 99), the immoral way is the happy one. Should we, however, consider Oscar Wilde to be approving of it? Clearly, 
Puşkin, M. (2021). Cautionary tale of the picture of Dorian Gray: Parable and autobiography. Humanitas, 9(18), 221-234.

we should now look at them more deeply and link them more to the story in order to rid the author of such critique.

\section{Lord Henry Wotton.}

Let us firstly focus on Lord Henry: arguably the most charming character and definitely the voice of the novel. Throughout the book he is praising the principles of hedonistic immoral life, but what is he gaining from it besides enjoying own wit? Unlike Dorian, Lord Henry is getting old - what is in stock for him? Carpe diem only works as long as one is young and can afford to be careless. First of all, we notice him deriving pleasure in moulding and subduing people around him, particularly Dorian, yet in the end he is the one left all alone outside the track of life of pleasures - it is the shiny never-fading Dorian, who can afford to live like there is no tomorrow every day. In the course of the novel Lord Henry talks lightly and ignorantly of his wife ("I hate the way you talk about your married life, Harry," said Basil Hallward" (Wilde, 1998, p. 12)), yet at the end he is very sad and reminiscent of her not being near anymore, but cannot admit to it instead transferring his emotions of the house: "The house is rather lonely without her. Of course, married life is merely a habit, a bad habit. But then one regrets the loss even of one's worst habits. Perhaps one regrets them the most." (Wilde, 1998, p. 262). Lord Henry is ashamed of becoming vulnerable with his heart open and broken converging with Basil (whose death purifies the world of the novel). Furthermore, as Dorian tells Lord Henry, that he killed Basil Hallward, Lord Henry cannot believe it - he too is caught in what he used to make fun of - the perception of the surface-deep (Dorian's) beauty over deeds (substance) or is even too frightened to accept the truth. He considers to have always been in control of Dorian, but now he cannot even comprehend what his "puppet" is capable of. When he is partially admitting the truth to himself, sad and confused, he questions Dorian on the source of the man's perpetual youth rather than challenging Dorian as he exclaims: "One should never do anything that one cannot talk about after dinner" (Wilde, 1998, p. 263). This underlines the difference between the Wilde's perspective on the amorality expressed through Lord Henry's aphorisms and the perception and action upon it by the society (by Dorian). Lord Henry only talks evil things throughout the book, - he does not, however commit them. "As for being poisoned by a book, there is no such thing as that. Art has no influence upon action" (Wilde, 1998, p. 269). Although realizing that his book has led Dorian to many a sin, - Lord Henry (rightfully?) does not take responsibility for it - it is indeed, the people, who act, - art (or the book) only portrays things being created (written) in a skilful manner. "All art is quite 
Puşkin, M. (2021). Cautionary tale of the picture of Dorian Gray: Parable and autobiography. Humanitas, 9(18), 221-234.

useless" (Wilde, 1998, p. 7), it might make things ugly seem aesthetic and beautiful, it might depict a murder as a desirable thing, but it only does so within the artistic paradigm, which is not that of the real world.

"Wilde seems to present an ironic celebration of aestheticism, at once supporting it and revealing the social anxiety, which inhabited attitudes towards art and culture. He appears even to observe faults in the aesthetic movement's creeds" (Matsuoka, 2003, p. 78).

People themselves are those, responsible for what they do under influence of art (book). One can take the "poisonous book" of Lord Henry as a metonymy to The Picture of Dorian Gray and the Dorian's perception of it as of an immoral guide book, - to the perception of the Victorian society of Oscar Wilde's novel. Lord Henry furthermore continues on that matter: "The books that the world calls immoral are books that show the world its own shame" (Wilde, 1998, p. 269). Clearly, Oscar Wilde here positions his response to the social criticism of The Picture of Dorian Gray. Therefore, one can say that the book is indeed wellwritten, but poorly read, or at least unjustly criticized.

\section{Sibyl Vane.}

Now coming back to the characters that fail in life in the book. Let us look at Sibyl Vane - indeed, her end is a dreadful one - to suicide after betrayal by the only man she loved, after having a first glance at the real life (after existing within the world of art almost entirely). This, however, is within the book and Lord Henry again is partially right, that her death is beautiful in it being akin to the great Shakespearean tragedies, that she so much adored performing. However, Oscar Wilde staged her tragic death not for Dorian to admire, and certainly not to excuse his heartlessness, but to tell something to us, the readers. When reading The Picture of Dorian Gray, one should keep in mind that characters are fictional and are there to illustrate something to us, rather than to be clear cut role models. Oscar Wilde goes beyond the boring straightforward moralistic tone, that earlier realistic novels have: "I never quarrel with actions. My one quarrel is with words. That is the reason I hate vulgar realism in literature. The man who could call a spade a spade should be compelled to use one. It is the only thing he is fit for" (Wilde, 1998, p. 240). Instead, he creates an image of a character, a situation, such that the readers could personally co-feel with and try to learn from and avoid in real life. In a way, he proves that an aesthetic novel can carry a moralistic message more real than that of traditional realistic novels.

The primary target of Wilde's aesthetic is realist art. Nineteenth century realism sought to accurately represent reality. [...] In so doing, realism yoked together morality and 
Puşkin, M. (2021). Cautionary tale of the picture of Dorian Gray: Parable and autobiography. Humanitas, 9(18), 221-234.

representation, because it advocated a moral stance based upon representation of reality, so that the moral ideas, like the objects, events, and people, represented commonly held opinions. In contrast, Wilde argued for an art of invention not representation, an art "dealing with what is unreal and non-existent". (Wilde, 1923, p. 27) Art should present an idealized creation that may have some relationship or similarity to reality but was not to represent reality. Even criticism, Wilde felt, should strive to be an art of perfection not representation (Peters, 1999, p. 2).

Indeed, Sibyl fails in life, or fails to live within the book, but she teaches the readers not to betray the loved ones, not to treat them like Dorian did. It is an example through the counterexample. "No artist is ever morbid. The artist can express everything. Thought and language are to the artist instruments of an art" (Wilde, 1998, p. 6).

\section{Basil Hallward.}

Very much similar is Basil Hallward's role, - sincere romantic, retired from life into his art, he is the one who feels soul in art and believes that there is soul in the people around him. He is someone, Oscar Wilde claims himself to be most like and indeed, it is Basil's kind and sincere nature, which brings about his end, being prophetic of the author's own life. Inside the world of The Picture of Dorian Gray he completes the triangle with Lord Henry and Dorian. While Lord Henry stands for the wit, Dorian - for the beauty, it takes the "soul" or conscience, which is Basil Hallward, to fill them with life. He provides the refuge of eternal beauty to Dorian; he provides Lord Henry with a toy that he could realize his experiments of hedonism with - like an advanced version of a beautiful painting. And he is also the one, who takes the blame through his death, redeeming self for what he has brought to life (Dorian).

He represents Wilde's attempt to write the novel for the people that would like the portrait of Dorian Gray, through the beauty of the language in which it is written, through its wit to show the ugliness of the Victorian society, reflect on it deeper than the paint of the portrait. To be able to distinguish the kindness inside. Furthermore, in paralleling Hallward with Wilde, we could say that like in the narrative, the painter dies before Dorian, just like Wilde died before the Victorian society he criticized fell apart. Oscar Wilde, just like Basil Hallward fell victim to his subject - the fascinating and rotten society he tried to change (Dorian).

\section{Immorality}

Speaking of the immorality of the book, one could generally discuss four aspects: the immoral deeds of Dorian, the immoral sayings of Lord Henry (already discussed), immorality 
Puşkin, M. (2021). Cautionary tale of the picture of Dorian Gray: Parable and autobiography. Humanitas, 9(18), 221-234.

of the book that Lord Henry gives to Dorian and the homoerotic imagery, which was considered immoral by the author's contemporaries (and still is by some of our contemporaries).

\section{Immoral deeds.}

What is indeed immoral about Dorian's deeds and how are they presented? First of all, the reader is not made aware of them all, - to the contrary, Wilde provides as little detail as possible (save for the murder of Basil): Dorian apparently leads astray a number of young men and women. After getting to know Dorian, they find their lives and reputations in ruins, some of them are then found in the opium dens, others suicide, more fortunate ones get away with only becoming outcasts of the society. The reader furthermore learns from Basil that Dorian is being accused of frequenting the opium dens in disguise, as well as brothels and other sully places, where a respectable gentleman should not go (Wilde, 1998, pp. 187-188). This again criticizes Victorian society, for if one is to notice Dorian in disguise in such places and recognize him, this person should be present there him- or herself. Against the lot of Basils accusations Dorian replies: “And what sort of lives do these people, who pose as being moral, lead themselves? My dear fellow, you forget that we are in the native land of the hypocrite" (Wilde, 1998, p. 188). With this he is implying that his alleged sins are merely a reflection of the age. These are the really immoral things that the reader hears about, without actually witnessing them in the narrative. Wilde does not entice us to delight in them together with Dorian. Thus, we cannot suggest that The Picture of Dorian Gray is immoral on the grounds of describing something utterly outrageous in attractive, favourable light. Now evil deeds of Dorian that we directly witness: murder of Basil, betrayal of Sybil, visit to the opium dens are by no means presented in the novel in a positive light (we have already discussed Sybil's case). Therefore, we cannot call The Picture of Dorian Gray immoral in this respect. In this sense then Wilde is writing a moral book. Even Basil's sacrifice leading to the destruction of the portrait and with it of Dorian is a form of purification resolving his worldview ideological conflict into bittersweet synthesis with Lord Henry.

Hallward himself says it was cowardice that made him wish to flee from the crisis of his life. Excessive conscience has made the artist afraid of life. Hallward's conscience, merged with Lord Henry's instinct, might have produced quite other results. As the novel stands, however, it is a tragedy of the artist-conscience untempered by the strength of hedonistic instinct and hedonism untempered by conscience. The artistic ideal represented by Dorian Gray moves rapidly toward the sensual corruption of hedonism, and only the destruction of the false ideal can return art to its pure state (Baker Jr, 1969, p. 355) 


\section{Homosexuality.}

What we did not discuss is homoerotic imagery of the novel. A subject to many a research paper that calls not for further endless reiteration as they are conclusively reviewed in When critics disagree: Recent approaches to Oscar Wilde (Bashford, 2002, pp. 613-617). Indeed, men are portrayed in a rather elaborate pretty and sensual manner, which would be more common for the description of women for the literature of the time. Furthermore, Basil's fascination with Dorian is clearly beyond the scope of just strong friendship: it is sincere overwhelming love, worship even: "Christ! what a thing I must have worshipped!" (Wilde, 1998, p. 195). Within this context it becomes reasonable to interpret his denial to exhibit the painting of Dorian because of what others might deduce from it, because of the fear that people will recognize his homosexual love and desire for Dorian. "The reason I will not exhibit this picture is that I am afraid that I have shown in it the secret of my own soul" (Wilde, 1998, p. 13), as he exclaims. However, Basil is quite clearly a romantic character type, an artist, - his feelings are ideal, - his love results in new mode of painting - he is not a person of bodily relationships. We can also interpret Lord Henry's desire for Dorian as homosexual, however, it is again just an assumption (since the book does not portray anything on that matter beyond their dialogue): his desire to seduce the young man is geared towards owning a precious toy upon which he can exercise power, to play it like the flute is what is made evident.

What is however essential (granted Wilde's own sexuality has found its way into the novel) homoerotic allusions are overt and by no means constitute the novel, - if they are altogether excluded, - the novel would not suffer qualitatively for anyone not concerned specifically with the issue.

All in all, however, this is the only point, which is difficult to debate in terms of morality, which is furthermore supported by Oscar Wilde's own sexual orientation and his speeches in favour of (as he claimed) homosexual relationships between men (younger and older ones) during the trial, paralleling them to such relationships between Plato and his students for example:

The love that dare not speak its name" in this century is such a great affection of an elder for a younger man. It is beautiful, it is fine, it is the noblest form of affection. There is nothing unnatural about it. It is intellectual, and it repeatedly exists between an older and a younger man, when the older man has intellect, and the younger man has all the joy, hope and glamour of life before him (Linder, 1895a). 
Puşkin, M. (2021). Cautionary tale of the picture of Dorian Gray: Parable and autobiography. Humanitas, 9(18), 221-234.

In this speech Wilde closely mirrors Basil, much as when pre-trial he exclaims "The train has gone. It's too late" (Linder, 1895b) again unwittingly impersonating Basil: "I see I have missed my train" (Wilde, 1998, p. 191).

Therefore, regarding the morality of The Picture of Dorian Gray, only the homoerotic aspect gives it the tint of bad reputation (if indeed paralleled with the author's life), which is by far balanced out with the moral messages that it brings to the reader.

\section{Well-written?}

Regarding well written, - there are many ways of verifying how well the book is written, one of them being its ability to survive through time. How many novels were written during Oscar Wilde's that time? Hundreds of thousands? More? How many have remained? Hundreds? Less? How many of those are read and enjoyed by the people of our time? Less than a hundred? The very fact that we still read and enjoy Wilde's works with some aphorisms in use to this day with the reading public, that it is being analysed academically, all stand testament to its immortality. Moreover, by now the novel has been transformed into numerous musicals, films and novels, - its motives are still present in literature, and its characters are still getting integrated into the very recent movies. It has become a legend. What makes it so well written to survive the test of time?

Although it is a novel about people, precisely about Victorian age society, do people really change that much? Apparently only a little bit, since all the sardonic aphorisms of Lord Henry are as understandable to us, as they were (but for all the denying) to Wilde's contemporaries.

Furthermore, what makes The Picture of Dorian Gray a masterpiece is that it discusses topics ever-present in our lives: love and tragedy, friendship, artworks, power and domination, youth and beauty, influence and its consequences. The novel does not only state beauty and youth to be influential for society as a critical element - Oscar Wilde himself worshiped beauty, its pure form. In suggesting that not judging by appearances is wrong he basically implied that if we are very attentive to people - their personality would shine through their appearance, violating the pure beauty. It is of course, a romantic point of view, expressed by Basil: "If a wretched man has a vice, it shows itself in the lines of his mouth, the droop of his eyelids, the moulding of his hands even" (Wilde, 1998, p. 186). That is why the first thing that changes on the portrait of Dorian - is the facial expression, - it is not age or disease that distort the image, but an individual cruelty. We may parallel the narrative of the novel to the changes in the portrait within it. They both start on a beautiful and peaceful note 
Puşkin, M. (2021). Cautionary tale of the picture of Dorian Gray: Parable and autobiography. Humanitas, 9(18), 221-234.

and as the narrative is progressing, - it is getting more and more dreadful, just like the portrait itself. Since the face of Dorian is the face of artwork that Basil painted, - the artist cannot see the evil behind it, because there is no evil in an artwork. "Art has no influence upon action. The books that the world calls immoral are books that show the world its own shame". In this specific case "there is no such thing as a moral or an immoral book" (Wilde, 1998, p. 6). This is portrayed in the novel by making the picture the only supernatural element, as if saying that beauty of art can only be combined with evil heart in a fictional world. Even so it is not the picture that commits Dorian's crimes, - he commits them himself.

Youth is something symbolic of purity - indeed with age comes experience and with experience and age come vices as youth leaves us. It is in a way forgivable of the society to read youth as innocence, since naturally two things co-follow. Beauty of an artwork or a theatre play in this sense is everlasting, since those objects are immortal and remain the same from the day they are born, just like Dorian's portrait or Cybil's performances (her last one she was not playing anymore), just like the novel itself - The Picture of Dorian Gray is always a young and beautiful book.

Speaking of the theme of friendship. out of three friends there is always an influence struggle (Basil loses in the beginning, but wins Dorian's heart and with it the hearts of the readers in the end), there are always complexities in feelings and understanding (Dorian kills Basil because the latter is capable to fully understand and express Dorian's feeling, something that he cannot bear). Although Basil dies, his image lives on through the book as Dorian's friend till the very end, while Lord Henry is losing the sharpness of his wit, gradually turning sentimental and sad, but is still next to Dorian, this time in a rather dependent position. Dorian even starts to deny Lord Henry, asking him not to give the poisonous yellow book to anyone. Deciding at last to become good, like Basil pictured him... This is a complex model, which most of us can trace in our own lives and relationships with people.

\section{Conclusion}

To conclude it would be appropriate to sum up the findings. In reading the novel in broader sense, one should heed Oscar Wilde's message: "There is no such thing as a moral or an immoral book. Books are well written or badly written. That is all” (Wilde, 1998, p. 6). While it can and should be understood on different levels, at each level The Picture of Dorian Gray triumphs over vulgar criticism and shallow reading. 
Puşkin, M. (2021). Cautionary tale of the picture of Dorian Gray: Parable and autobiography. Humanitas, 9(18), 221-234.

Secondly, there is no need to defend this specific book on the grounds of morality, as it is largely moral (in its message) and even more effective in conveying high morality than many of its predecessors (arguably more so than the author's real life, which it mirrors).

Thirdly, it is well-written in respect to its being always contemporary in a sense through dealing with universal ideas, which are present in humanity's life since its beginning and have a good chance of staying there till its possible end.

And fourthly any good book is a work of art, and a work of art does not in itself possess any characteristic but the ones we can read from it, just like the nature itself exists regardless of people's labels. Therefore, a reader, who approaches The Picture of Dorian Gray with an open and kind heart like that of Basil's will read the sad, the beautiful and the kind out of it... 
Puşkin, M. (2021). Cautionary tale of the picture of Dorian Gray: Parable and autobiography.

\section{References}

Baker Jr, H. A. (1969). A tragedy of the artist: the picture of Dorian Gray. Nineteenth-Century Fiction, 24(3), 349-355.

Bashford, B. (2002). When critics disagree: recent approaches to Oscar Wilde. Victorian Literature and Culture, 30(2), 613-625.

Clausson, N. (2003). Culture and corruption: paterian self-development versus gothic degeneration in Oscar Wilde's the picture of Dorian Gray. Papers on Language and Literature, 39(4), 339-364.

Frankel, N. (2011). Textual introduction. In O. Wilde, \& N. Frankel (Ed.), The picture of Dorian Gray: an annotated, uncensored edition (pp. 38-64). Cambridge: Harvard University Press.

Liebman, S. W. (1999). Character design in the picture of Dorian Gray. Studies in the Novel, 31(1), 296-316.

Linder, D. O. (1895). Testimony of Oscar Wilde. Famous trials. https://www.famoustrials.com/wilde/342-wildetestimony

Linder, D. O. (1895). The trials of Oscar Wilde: an account. Famous trials. https://www.famous-trials.com/wilde/327-home

Matsuoka, M. (2003). Aestheticism and social anxiety in the picture of Dorian Gray. Journal of Aesthetic Education, 29, 77-100.

Nunokawa, J. (1996). The importance of being bored: the dividends of ennui in the picture of Dorian Gray. Studies in the Novel, 28(3), 357-371.

Oates, J. (1988). The picture of Dorian Gray: Wilde's parable of the fall. In O. Wilde, \& D. L. Lawler (Ed.), The picture of Dorian Gray (pp. 422-431). New York: W. W. Norton.

Pearce, J. (2001). The unmasking of Oscar Wilde. London: Harper Collins.

Peters, J. G. (1999). Style and art in Wilde's the picture of Dorian Gray: form as content. Victorian Review, 25(1), 1-13.

Wilde, O. (1923). Decay of Lying. In Complete works of Oscar Wilde, patron's edition deluxe (Vol. 5). Garden City: Doubleday.

Wilde, O. (1966). The complete works of Oscar Wilde. London: Collins.

Wilde, O. (1998). The picture of Dorian Gray. London: The Electric Book Company.

Wilde, O. (2002). The complete letters of Oscar Wilde. (M. Holland, \& R. Hart-Davis, Eds.) New York: Henry Holt. 